\title{
GAMBARAN TINGKAT PENGETAHUAN PASANGAN USIA SUBUR (PUS) TENTANG MANFAAT INISIASI MENYUSU DINI DI DESA SIALAGUNDI KECAMATAN SIPIROK
}

\author{
Nurhanifah Siregar, Lena Juliana Harahap,", Juliana Lubis ${ }^{3}$ \\ ${ }^{1}$ STIKes Darmais Padangsidimpuan, Padangsidimpuan, Indonesia \\ Email: ${ }_{1 \text { nurhanifahsiregar90@ gmail.com }}^{2}$,*Lenajulianahrp@gmail.com \\ ${ }^{3}, *$ julilubis17@gmail.com \\ * Nurhanifah Siregar
}

\begin{abstract}
Abstrak
Inisiasi Menyusu Dini (IMD) adalah meletakan bayi secara tengkurap di dada atau perut ibu sehingga kulit bayi melekat pada kulit ibu yang dilakukan sekurang-kurangnya satu jam segera setelah lahir. Inisiasi Menyusu Dini (IMD) berperan dalam membantu menurunkan angka kematian anak dan balita. IMD juga dapat meningkatkan keberhasilan ASI eksklusif dan lama menyusui sampai 2 tahun. Jenis penelitian ini adalah Survey Cross Sectional dengan sampel 85 responden, yang diteliti adalah pengetahuan pasangan usia subur tentang manfaat inisiasi menyusu dini berdasarkan umur, pendidikan, pekerjaan, paritas, sumber informasi,dan teknik pengambilan sampel adalah total sampling. Data dikumpul dengan menggunakan kuesioner. ,yang diteliti adalah pengetahuan pasangan usia subur tentang manfaat inisiasi menyusu dini berdasarkan umur, pendidikan, pekerjaan, paritas, sumber informasi, dan teknik pengambilan sampel adalah total sampling. Data dikumpul dengan menggunakan kuesioner. Hasil penelitian tingkat pengetahuan berdasarkan umur mayoritas pengetahuan kurang sebanyak 65 orang $(97,0 \%)$. Berdasarkan pendidikan ialah SMA dengan tingkat pengetahuannya semua berpengetahuan kurang. Berdasarkan pekerjaan yang berpengetahuan kurang sebanyak 33 orang $(97,0 \%)$. Berdasarkan paritas ialah multigravida yaitu 37orang $(43,5 \%)$ yang berpengetahuan kurang sebanyak 34 orang $(91,9 \%)$. Berdasarkan cara memperoleh informasi dari sumber media elektronik sebanyak 50 orang $(58,8 \%)$ yang berpengetahuan kurang sebanyak 45 orang $(90,0 \%)$.
\end{abstract}

Kata Kunci : Inisiasi Menyusu Dini, Pengetahuan

\begin{abstract}
Early Breastfeeding Initiation (IMD) is placing the baby on his stomach on the mother's chest or abdomen so that the baby's skin is attached to the mother's skin, which is carried out at least one hour immediately after birth. Early Initiation of Breastfeeding (IMD) plays a role in helping reduce child and under-five mortality. IMD can also increase the success of exclusive breastfeeding and breastfeeding duration up to 2 years. This type of research is a Cross Sectional Survey with a sample of 85 respondents, which is studied is the knowledge of couples of childbearing age about the benefits of early initiation of breastfeeding based on age, education, occupation, parity, sources of information, and the sampling technique is total sampling. Data were collected using a questionnaire. . the results of the study of the level of knowledge based on the age of the majority of knowledge were 65 people (97.0\%). Based on education, it is high school with the level of knowledge all of them are less knowledgeable. Based on the work with less knowledge as many as 33 people (97.0\%). Based on parity, there were 37 people (43.5\%) who were multigravida and 34 people $(91.9 \%)$. Based on how to obtain information from electronic media sources as many as 50 people (58.8\%) with less knowledge as many as 45 people (90.0\%).
\end{abstract}

Keywords: Early Initiation of Breastfeeding, Knowledge 


\section{Pendahuluan}

Inisiasi Menyusu Dini (IMD) adalah meletakan bayi secara tengkurap di dada atau perut ibu sehingga kulit bayi melekat pada kulit ibu yang dilakukan sekurang-kurangn y a satu jam segera setelah lahir. Jika kontak tersebut terhalang oleh kain atau dilakukan kurang dari satu jam dianggap belum sempurna dan dianggap tidak melakukan IMD.

Inisiasi Menyusu Dini (IMD) adalah perilaku pencarian puting payudara ibu s a at setelah lahir. Ketua Umum Sentra Laktasi Indonesia yakni Roesli yang menjelaskan bahwa pada IMD bayinya diharapkan beru saha untuk menyusu. Pada jam per tam a b ay i berhasil menemukan payudaraibunya. Inilah awal hubungan menyusui antar a bay i d an ibunya (Prasetyono, n.d.)

Berdasarkan penelitian WHO di enam Negara berkembang resiko kem atian bayi meningkat $40 \%$ jika bayi tersebut tidak disusui. Jika berusia dibawah d u a bu lan an gka kematian ini meningkat menjadi $480 \%$. Inisiasi Menyusu Dini dapat men gu rangi $22 \%$ kematian bayi usia 28 hari. Berarti Inisiasi Menyusu Dini (IMD) mengurangi angka kematian Balita 8,8\% (Roesli, 2008).

Hasil Pemantauan Status Gizi (PSG) tahun 2016, persentase bayi baru lah ir y ang mendapat IMD pada tahun 2016 sebesar 51,9\% yang terdiri dari $42,7 \%$ men d ap atkan IMD dalam < 1 jam setelah lahir, dan 9,2\% dalam satu jam atau lebih. Persentase tertinggi di Provinsi DKI Jakarta (73\%) dan terendah Bengkulu (16\%) (Kemenkes, 2016)

Hasil Pemantauan Status Gizi (PSG) tahun 2017, persentase bayi baru lahir y ang mendapat IMD pada tahun 2017 sebesar 57,97\%. Yang terdiri dari 51,32\% mendapatk an IMD dalam < 1 jam setelah lahir, Persentase tertinggi di provinsi Sumatra Selatan $(62,26 \%)$ dan terendah Papua $(25,01 \%)$. Dan $6,65 \%$ dalam $\geq 1$ jam atau lebih, persentase tertinggi di provinsi D.I Yogyakarta $(20,20 \%)$ dan terendah Sumatra Selatan $(2,01 \%)$ (Kemenkes, 2017)

Menyusui sejak dini mempunyai dampak yang positif untuk ibu dan bayinya. Menyusui memiliki peranan penting untuk menunjang pertumbuhan, kesehatan, dan kelangsungan hidup bayi karena ASI kaya akan zat gizi dan antibody. untuk ibu, menyusui dapat mengurangi morbiditas dan mortalitas karena pada saat proses menyusu $i$ bisa merangsang kontraksi uterus sehingga dapat mengurangi perdarahan pasca melahirkan (postpartum). Menyusui dalam jangka panjangjuga dapat mem perpanjang jarak kelahiran karena masa amenorhoe lebih panjang.

Inisiasi menyusu dini diyakini dapat membantu meningkatkan daya tah an tubuh terhadap penyakit yang beresiko tinggi seperti kanker sistem syaraf, leukemia, dan berbagai penyakit lainnya. Pemberian ASI Eksklusif selama enam bulan pertama kehidupan dapat mencegah kematian dari sekitar 1,3 juta bayi di seluruh dunia setiap tahunnya (Roesli, 2008). 
Tingkat pencapain IMD di beberapa negara masih sangat rendah. Di Eropa Timur d an Asia Tengah hanya sebesar 17\%, sedangkan di Asia Pasifik sebesar 33\%, padahal IMD dapat mengurangi kematian neonatal sebesar $22 \%$, bila dibandingkan dengan negaranegara lain, pencapain IMD di Indonesia masih sangat rendah. Kurangny a pe mah am an tentang IMD dan pemberian ASI secara ekslusif, sehingga pelaksanaan IMD dan pemberian ASI secara ekslusif tidak dihiraukan. IMD harus dilakukan langsung saat lahir, tanpa boleh di tunda dengan kegiatan menimbang atau mengukur bayi. Bayi tidak boleh dibersihkan hanya dikeringkan kecuali tangannya. Salah satu manfaat IMD y aitu dapat menyelamatkan hidup satu juta bayi (Ramlan, Hadju, \& Sirajuddin, 2014).

Menurut penelitian yang dilakukan di Ghana dan diterbitkan dalam jurnal ilmiah Pediatrics, 22\% kematian neonatal dapat dicegah bila bayi disusui oleh ibunya dalam satu jam pertama kelahiran. Mengacu pada hasil penelitian itu, maka diperkirak an program Inisiasi Menyusu Dini dapat menyelamatkan sekurang-kurangnya 30.000 bayi Indone s ia yang meninggal dalam bulan pertama kelahiran (Pebriani, 2012).

Berikut ini gambaran Angka Kematian Bayi di Provinsi Sumatera Utara berdasarkan hasil Sensus Penduduk (SP). Berdasarkan dua sensus sebelumnya (yaitu data sensus tahun 2000 dan 2010), angka kematian bayi di Sumatera Utara telah menurun secara signifikan. Akibat SP 2000, AKB Sumut menjadi 44/1000 KH kemudian tu run menjadi 25,7 atau dibulatkan menjadi 26/1000.1000 KH termasuk dalam hasil SP 2010 . Jika melihat tren AKB periode 2001-2010, dapat dihitung bahwa setiap tahun terjadi penurunan, yang diperkirakan rata-rata 1,8 per $1.000 \mathrm{KH}$ per tahun. . Oleh karena itu, jika tren penurunan AKB dapat dipertahankan, maka AKB Sumut tahun 2016 diperkirak an sebes ar 15,2/1000 KH.Dari data yang diperoleh sebanyak 12 orang bayi meninggal dari 298 kelahiran dalam kurun waktu satu tahun. Dan bayi yang melaksanakan IMD (Inisiasi Menyusu Dini) sebanyak 160 orang $(53,69 \%)$ dalam setahun (Dinas Kesehatan Tapanuli Selatan, 2017).

Berdasarkan data diatas sehingga peneliti tertarik untuk melakukan penelitian yang berjudul " Tingkat Pengetahuan Pasangan Usia Subur (PUS) Tentang Manfaat Inisiasi Menyusu Dini di Desa Sialagundi Kecamatan Sipirok”

\section{Metode Penelitian}

Penelitian ini menggunakan metode penelitian observasional analitik dengan rancangan penelitian cross sectional. Penelitian ini dilakukan di desa Sialagundi Kecamatan Sipirok Kabupaten Tapanuli Selatan. Populasi penelitian ini adalah s elu ru h pasangan usia subur di desa Sialagundi sebanyak 85 orang. Sampel dalam penelitian ini adalah total selururuh populasi yaitu 85 orang. Analisis data dilakukan secara an alisis deskriftif yaitu dengan melihat persentase data yang terkumpul dan disajikan dalam tabel frekuensi. Analisis data kemudian dilanjutkan dengan membahas penelitian sesuai dengan teori dan kepustakaan yang ada. 


\section{Hasil Dan Pembahasan}

\section{Hasil}

\section{Distribusi Frekuensi Karakteristik PUS}

Berdasarkan distribusi frekuensi PUS berdasarkan umur, pendidikan, pekerjaan, paritas dan sumber informasi dapat dilihat pada tabel dibawah ini

Tabel 1

Distribusi Frekuensi Karakteristik PUS Berdasarkan Umur, Pendidikan, Pekerjaan, Paritas dan Sumber Informasi Di Kecamatan Sipirok Desa Sialagundi

\begin{tabular}{|c|c|c|}
\hline Karakteristik & Frekuensi & Presentase \\
\hline \multicolumn{3}{|l|}{ Umur : } \\
\hline a. 20-29 tahun & 67 & 78.9 \\
\hline b. 30-39 tahun & 18 & 21.1 \\
\hline Total & 85 & 100.0 \\
\hline \multicolumn{3}{|l|}{ Pendidikan : } \\
\hline a. SD & 7 & 8.2 \\
\hline b. SMP & 10 & 11.8 \\
\hline c. SMA & 60 & 70.6 \\
\hline d. Perguruan Tinggi & 8 & 9.4 \\
\hline Total & 85 & 100.0 \\
\hline \multicolumn{3}{|l|}{ Pekerjaan : } \\
\hline a. Pedagang & 13 & 15.3 \\
\hline b. Buruh / tani & 34 & 40.0 \\
\hline c. Wiraswasta & 20 & 23.5 \\
\hline d. IRT & 18 & 21.2 \\
\hline Total & 85 & $\mathbf{1 0 0 . 0}$ \\
\hline \multicolumn{3}{|l|}{ Paritas : } \\
\hline a. Primigravida & 35 & 41.2 \\
\hline b. Multigravida & 37 & 43.5 \\
\hline c. Grandemultigravida & 13 & 15.3 \\
\hline Total & 85 & 100.0 \\
\hline \multicolumn{3}{|l|}{ Sumber Informasi : } \\
\hline Media Cetak & 5 & 5.9 \\
\hline Media Elektronik & 50 & 60.0 \\
\hline Tenaga Kesehatan & 30 & 34.1 \\
\hline Total & 85 & 100.0 \\
\hline
\end{tabular}

Berdasarkan Tabel 2 menunjukkan bahwa karakteristik PUS berdasarkan u mu r mayoritas berumur 20-29 tahun sebanyak 67 orang $(78,9 \%)$. Berd as ark an pen didikan mayoritas resspoden berpendididkan SMA yaitu sebanyak 60 orang $(70,6 \%)$. Berdasarkan pekerjaan umunya bekerja sebagai buruh/tani sebanyak 34 orang $(40,0 \%)$. Berd a s ark an 
paritas mayoritas telah memiliki anak lebih dari satu yaitu multigravida sebanyak 37 orang (43.5\%). Dan berdasarkan sumberinformasi mayoritas PUS di Des a Sialagundi mendapatkan informasi dari media eletronik sebanyak 50 orang $(58,8 \%)$.

\section{Tingkat Pengetahuan Responden tentang manfaat Inisiasi Meny usu Dini}

Berdasarkan distribusi frekuensi PUS berdasarkan Tingkat Pengetahuan dapat dilihat pada tabel dibawah ini.

Tabel 1

Distribusi Frekuensi Karakteristik PUS Berdasarkan Tingkat Pengetahuan

\begin{tabular}{|c|c|c|}
\hline Pengukuran Pengetahuan & Frekuensi & Persentase \\
\hline Baik & 1 & 1.2 \\
\hline Cukup & 8 & 9.4 \\
\hline Kurang & 76 & 89.4 \\
\hline Total & 85 & 100.0 \\
\hline
\end{tabular}

Berdasarkan Tabel 1 menunjukkan bahwa pengetahuan PUS tentang manfaat Inisiasi Menyusui Dini di Desa Sialagundi dengan pengetahuan baik sebayak 1orang respoden $(1,2 \%)$ Pengetahuan cukup sebanyak 8 orang responden $(9,4 \%)$ dan pengetahuan kurang sebanayak 76 responden $(89,4 \%)$.

\section{Pembahasan}

Pengetahuan (knowledge) merupakan hasil tahu dari manusia, yang sekedar m en jaw ab pertanyaan " what ", misalnya apa air, apa manusia, apa alam, dan sebagainya. Pengetahuan hanya dapat menjawab pertanyaan apa sesuatu itu (Notoatmodjo,2010)

Pengetahuan merupakan segala apa yang diketahui berdasarkan pengalaman y ang didapatkan oleh setiap manusia. Semakin banyak berpengetahuan kurang. Fak tor y ang mempengaruhi pengetahuan seseorang adalah pendidikan, usia, pengalaman, lingkungan, paritas dan sumber informasi (Mubarak, 2011)

\section{Pengetahuan Pasangan Usia Subur (PUS) tentang manfaat Inisiasi Menyusu Dini Ditinjau dari Umur \\ Menurut (Isna, 2011) orang yang lebih muda mempunyai daya ingat yang lebih} kuat dan kreativifitas yang lebih tinggi dalam mencari dan mengenal sesuatu yang belu m di ketahui di bandingkan dengan orang yang usianya lebih tua. Hasil penelitian menunjukkan bahwa mayoritas pasangan usia subur (PUS) di desa Sialagundi berdasarkan umur ialah 20-29 tahun sebanyak 67 orang (78,9\%) Apabila diuraikan berdasarkan tingkat pengetahuannya yaitu yang pengetahuan baik ada sebanyak 1 or an $g$ $(1,7 \%)$ yang berpengetahuan cukup 1 orang $(1,5 \%)$ dan yang berpengetahuan kurang yaitu sebanyak 65 orang $(97,0 \%)$.

Kondisi Pasangan Usia Subur di desa Sialagundi diatas terlihat bahwa may oritas berusia muda (20-29 tahun). Tetapi sekitar 63 orang $(94,0 \%)$ mempunyai pen getahuan kurang, padahal sesuai dengan yang diperoleh, kemampuan untuk menyerap pengetahuan baru lebih mudah dilakukan pada umur yang lebih muda karena otak berfungsi maksimal pada usia yang lebih muda. Mungkin hal ini disebabkan oleh kurangnya informas i y ang 
di peroleh dan juga kurangnya motivasi pas angan usia subur untuk melaksanakan inisiasi menyusu dini tersebut.

Apabila dilihat dari hasil penelitian yang telah dilakukan mayoritas responden masih berusia muda, berbeda dengan teori di atas yang mengatakan bah wa orang y ang lebih muda mempunyai daya ingat yang lebih kuat dan kreatifitas yang lebih tinggi. Pad a kenyataannyares ponden di desa Sialagundi yang masih berusia muda tidak terlalu peduli dengan kesehatan, mereka cenderung mengikuti kebiasaan yang di wariskan oleh ibu ataupun mertuanya dalam hal persalinan, sehingga walaupun masih berusia muda mereka masih kurang aktif dalam mencari informasi.

\section{Pengetahuan Pasangan Usia Subur (PUS) tentang manfaat Inisiasi Menyusu Dini Ditinjau dari Pendidikan}

Berdasarkan hasil penelitian diketahui bahwa mayoritas pasangan usia subur(PUS) di desa Sialagundi berdasarkan pendidikan ialah SMA sebanyak 60 orang $(70,6 \%)$ dengan tingkat pengetahuannya semua berpengetahuan kurang. Dari hasil penelitian tersebut menunjukkan bahwa walaupun seseorang itu sudah berpendidikan tinggi buk an berarti mempunyai pengetahuan yang tinggi tentang manfaat inisiasi menyusu dini. Dari 60 responden yang berpendidikan SMA seharusnya hal ini mempermudah menyerap informasi yang ada dibandingkan pasangan usia suburyang berpendidikan lebih rendah seperti SMP atau SD.

Dari hasil penelitian di atas didasarkan pendapat (Mubarak, 2012) yang menyebutkan, pendidikan berarti bimbingan yang diberikan ses orang terhadap orang lain agar dapat memahami sesuatu hal. Tidak dapat di pungkiri bahwa semakin tinggi pendidikan seseorang, semakin mudah menerima informasi, dan pada akhirnya pengetahuan yang dimilikinya akan semakin meningkat. Sebaliknya jika tingkat pengetahuan seseorang rendah, akan menghambat perkembangan sikap or an g ters ebu t untuk menerima informasi dan nilai-nilai baru di perkenalkan.

Pasangan usia suburdi desa Sialagundi yang mayoritas berpendidikan SMA semua berpengetahuan kurang. Apabila dilihat dari program pemerintah yang masih mewajibkan pendidikan 9 tahun seharusnya dari program ini diharapkan bahwa orang yang berpendidikan SMA mempunyai pengetahuan yang cukup dan lebih giat mencari informasi. Namun yang peneliti temukan di desa Sialagundi adalah bahwa sekalipun seseorang berpendidikan tinggi itu tidak bisa dijadikan sebagai tolak ukur bahwa merek a berpengetahuan yang cukup misalnya dalam bidang kesehatan. Karena memang pendidikan seperti manfaat inisiasi menyusu dini ini tidak didapatkan disekolah baik itu SMP dan SMA. Disini diharapkan PUS yang lebih rajin mencari informasi-informasi yang bermanfaat. Dan teorinya didukung oleh program pemerintah melalui Pu s kes mas dan jaringannya yang lebih mensosialis asikan manfaat IMD.

\section{Pengetahuan Pasangan Usia Subur (PUS) tentang manfaat Inisiasi Menyusu \\ Dini Ditinjau dari Pekerjaan}

Lingkungan pekerjaan dapat membuat seseorang akan memperoleh pen galam an dan pengetahuan, baik secara langsung maupun tidak lansung (Mubarak, 2011) Ada banyak jenis pekerjaan di indonesia yang bias dijadikan sebagai sumber mata pencaharian, diantaranya buruh/tani, pedagang dan wiraswasta. Dari hasil penelitian diperoleh bahwa mayoritas pas angan usia subur(PUS) di desa Sialagundi berdas ark an pekerjaan ialah Buruh/tani sebanyak 34 orang $(40,0 \%)$ yang memiliki pengetahuan cukup sebanyak 1 orang $(3,0 \%)$ dan yang pengetahuan kurang ada sebanyak 33 orang $(97,0 \%)$.

Mayoritas pasangan usia subur di desa Sialagundi tidak ada yang bekerja di bidan g kesehatan, kecuali bidan desa yang di tempatkan di desa tersebut. Hal ini tentunya mempengaruhi tingkat pengetahuan pasnagan usia subur tentang manfaat inisiasi 
menyusu dini, karena masih kurang terpapar dengan informasi tentang pentingnya melaksanakan inisiasi menyusu dini dan masih kurangnya motivasi baik itu dari suami dan keluarga.

Kesimpulan yang peneliti peroleh setelah melakukan penilitan tentang tingkat pengetahuan pasangan usia subur tentang manfaat inisiasi menyusu dini mas ih kurang dikarenakan mayoritas yang bekerja sebagai buruh/tani kurang berinteraksi satu sama lain dan berbagi informasi. Yang disebsbkan pekerja buruh/tani ini kurang terpapar informasi kesehatan. Karna lebih banyak menghabiskan waktu untuk bekerja di ladang atau di sawah dan juga tidak terlalu sering mengikuti kegiatan prnyuluhan yang dilakukan tenaga kesehatan dengan alas an sibuk bekerja.

\section{Pengetahuan Pasangan Usia Subur (PUS) tentang manfaat Inisiasi Menyusu Dini Ditinjau dari Paritas}

Dari hasil penelitian diketahui bahwa mayoritas pas angan usia subur (PUS) di desa Sialagundi berdasarkan paritas ialah multigravida yaitu sebanyak 37 orang $(43,5 \%)$ y ang berpengetahuan baik sebanyak 1 orang $(2,7 \%)$ yang berpengetahuan cukup s eb an yak 2 orang $(5,4 \%)$ sementara yang berpengetahuan kurang sebanyak 34 orang $(91,9 \%)$.

Primigravida adalah seorang wanita yang hamil untuk pertama kali. Multigravida atau pleupara adalah wanita yang pernah hamil bayi viable beberapa kali (sampai 5 kali). Grandemultigravida adalah wanita yang pernah hamil 6 kali atau lebih, hid up atau pu n mati.

Dilihat dari hasil penelitian yang mayoritas multigravida, seharusnya pasangan usia subur tersebut lebih banyak tahu mengenai Inisiasi Menyusu Dini karna sudah me miliki pengalaman dari proses pada saat persalinan sebelumnya. Tetapi selama ini pas angan usia subur kerang termotivasi untuk melaksankan inisiasi menyusu dini.

Seharusnya apabila dilihat dari may oritas yang sudah multigravida pasangan u sia subur di desa sialagundi ini sudah tahu apa manfaat inisiasi menyusu dini tersebut. Namun kembali lagi pada dukungan dan motivasi dari keluarga, dari kebiasaan yang saya lihat orang tua selalu mengatakan, pada masa dia melahirkan dulu pun tidak dilaksan kan inisisasi menyusu dini anak-anaknya tetap hidup sehat. Sehingga ia melarang pelaks an an inisiasi dini dilakukan karna tidak seusai dengan pengalaman dia dulu pada saat melahirkan dan kasihan melitat bayi yang langsung di tengkurapkan ke dada ibu, ibu hawatir bayi akan kesulitan bernafas.

\section{Pengetahuan Pasangan Usia Subur (PUS) tentang manfaat Inisiasi Menyusu Dini Ditinjau dari Sumber Informasi}

Dalam pembahas an ada tiga kategori sumber informasi yang di cantumkan sebagai sarana informasi yang sering di gunakan oleh masyarakat yaitu :
a. Media cetak
: Majalah, Koran, Surat kabar
b. Media elektronik : Radio, TV, Internet, Film atau Video
c. Tenaga kesehatan : Dokter, Bidan, Perawat

Dari hasil penelitian diketahui bahwa mayoritas pas angan usia subur (PUS) di desa Sialagundi memperoleh informasi dari sumber media elektronik sebanyak 50 orang $(58,8 \%)$ tetapi dari 50 orang yang berpengetahuan cukup sebanyak 5 orang $(10,0 \%)$ d an berpengetahuan kurang sebanyak 45 orang $(90,0 \%)$.

\section{Kesimpulan}

Berdasarkan hasil penelitian ditarik kesimpulan bahwa tingkat pengetahuan Pasangan Usia Subur (PUS) tentang manfaat Inisiasi Menyusui Dini di Desa Sialagund i dengan pengetahuan baik sebayak 1 orang respoden $(1,2 \%)$ Pengetahuan cukup sebany ak 8 orang responden $(9,4 \%)$ dan pengetahuan kurang sebanayak 76 responden $(89,4 \%)$. 


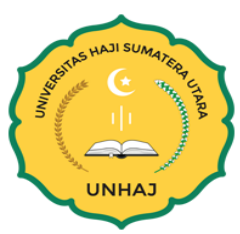

\section{DAFTAR PUSTAKA}

Isna, H. (2011). Promosi Kesehatan untuk Kebidanan. Nuha Medika.

Kemenkes. (2017). Profil Kesehatan. Pusat Data Dan Informasi Kementrian Keshatan RI, 119-121.

Kemenkes, 2016. (2016). Profil Kesehatan.

Mubarak, W. I. (2011). Promosi kesehatan untuk kebidanan.

Mubarak, W. I. (2012). Ilmu Kesehatan Masyarakat. Jakarta: Salemba. Medika.

Notoatmodjo, S. (2010). Ilmu kesehatan masyarakat, rineka cipta. Jakarta.

Pebriani, 2012. (2012). pengetahuan, sikap, dan tindakan petugas kesehatan dalam kegiatan Inisiasi Menyusu Dini di Wilayah Kerja Puskesmas Sayurmatinggi Kec.Sayurmatinggi Kab.Tapanuli Selatan Tahun 2011.

Prasetyono, D. S. 2009. (n.d.). Buku Pintar ASI Eksklusif. Yogyakarta: Diva Press.

Ramlan, S., Hadju, V., \& Sirajuddin, S. (2014). Edukasi Inisiasi Menyusu Dini Terhadap Pengetahuan Sikap Ibu Hamil di RSIA Pertiwi Makassar. Makassar.

Roesli, U. 2008. (2008). Inisiasi Menyusu Dini. Jakarta. 